\title{
Pearls \& Oy-sters: The Myasthenic Double Humps
}

Brian D. Stephens, MD, MS, and Min K. Kang, MD

Neurology ${ }^{\circledR}$ 2021;96:545-547. doi:10.1212/WNL.0000000000011287
Correspondence

Dr. Stephens

Stephensbd@gmail.com

\section{Pearls}

- Congenital myasthenic syndrome (CMS) is an important diagnosis to consider in an adult with both fixed and fatigable weakness.

- Repetitive compound muscle action potentials (CMAPs) or "double humps" on routine nerve conduction studies can be a clue in certain subtypes of CMS such as acetylcholine receptor (AChR) defect and acetylcholinesterase deficiency.

- Slow channel CMS is a subtype of CMS caused by an autosomal dominant gain of function mutation in the AChR, clinically characterized by cervical and distal weakness.

\section{Oy-sters}

- Failure to consider this diagnosis may delay diagnosis and cause harm to the patient.

- Identification of the genetic subtype has clinical importance due to variable or detrimental response to treatments.

- Treatment of slow channel CMS relies on decreasing the duration of AChR opening with agents such as fluoxetine and quinidine.

A 38-year-old woman presented for progressive weakness and fatigue. She initially experienced fatigable weakness after giving birth to her first child. Gradually she developed difficulty holding up her head at the end of a day. She also could not tolerate walking or standing for a long time. She denies droopy eyelids or double vision. She has tried to work outside the home in the past but states she has never been able to hold a job because of her fatigue.

The patient's developmental history is only significant for delayed walking (age 2 or 3 years old). Her family history is notable for a brother and 2 cousins who carry the diagnosis of seronegative myasthenia gravis and a 3-year old daughter with genetically confirmed CMS. Her 8 -year old son does not carry a genetic mutation for CMS.

The patient's physical examination revealed mild ptosis at rest in primary gaze and symmetrical mild to moderately limited extraocular movements most prominent during horizontal ductions. A curtain sign was present bilaterally. She had mildly decreased excursion on smile and Medical Research Council grade 4 strength on neck flexion and extension. She had grade 4 weakness throughout her arms except on wrist and finger flexion. Her legs were full strength except grade 4 weakness on bilateral hip flexion. Her reflexes, sensation, coordination, and gait were all within normal limits.

The patient's laboratory workup up to this point was significant for a creatine kinase level of $57 \mathrm{U} / \mathrm{L}$ (normal); negative AChR binding, blocking, and modulating antibodies; and negative muscle-specific tyrosine kinase antibodies.

Routine motor and sensory nerve conduction studies of the right arm showed normal amplitude, latencies, and conduction velocities. Analysis of the median and ulnar motor wave forms demonstrated repetitive CMAPs (figure). Repetitive nerve stimulation (RNS) revealed decremental response at $1,2,3$, and $5 \mathrm{~Hz}$. The repetitive CMAP abolishes with increasing RNS frequency (figure). 
Figure Characteristic Repetitive Compound Muscle Action Potential (CMAP) and Abolishment With Repetitive Nerve Stimulation

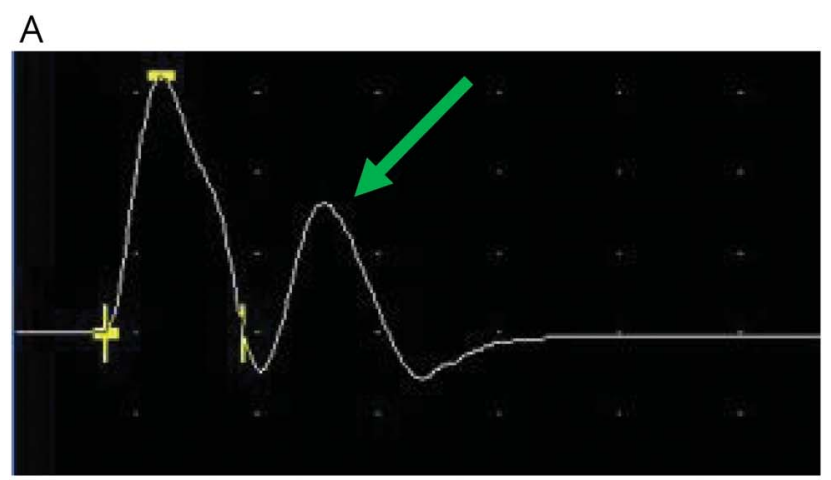

B
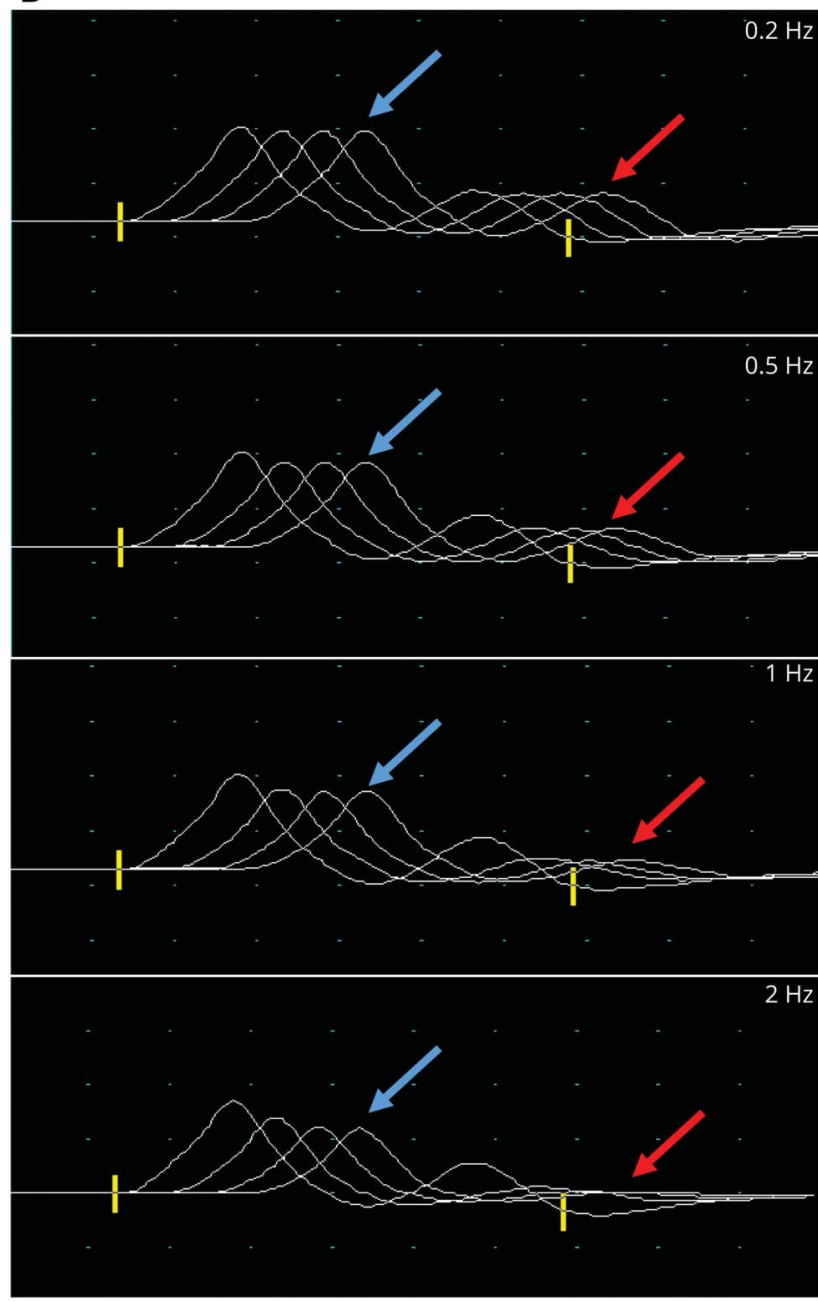

(A) Single stimulus applied to the median nerve at the wrist (shown) evokes a repetitive CMAP (green arrow). (B) Repetitive nerve stimulation of the ulnar nerve at increasing frequencies to $0.2,0.5,1$, and $2 \mathrm{~Hz}$ demonstrates decrement of the primary CMAP (blue arrows) and abolishment of the repetitive CMAP (red arrows) in higher frequencies.

Genetic panel testing confirmed a pathogenic variant in the CHRNB1 gene (c.865G>A), which is the same genetic variant carried by the patient's daughter. This abnormality causes a slow-channel myasthenic syndrome due to a mutation in the $\beta-1$ subunit of $A C h R$. The patient was prescribed fluoxetine for treatment of her condition and has plans to start this soon.

\section{Discussion}

CMS are a heterogeneous group of disorders caused by genetic defects in the proteins involved in neuromuscular junction structure, function, and repair. ${ }^{1}$

CMS can be caused by presynaptic, synaptic, or postsynaptic dysfunction. The most common CMS are the postsynaptic forms, and specifically those due to mutations in the genes encoding subunits of the muscle nicotinic AChR, causing kinetic changes that can be classified as either fast-channel or slow-channel syndromes. As was the case in this patient, slowchannel CMS is an autosomal dominant gain-of-function mutation in the AChR that causes a prolonged decay of the synaptic current. ${ }^{2}$ This prolonged open time of the AChR results in entry of calcium ions into the muscle fiber, resulting in an endplate myopathy. ${ }^{3}$

CMS are misdiagnosed initially in the majority of patients and can take decades from onset of symptoms to correct diagnosis. ${ }^{4}$ Clinically, in addition to fatigable weakness, a clue to the diagnosis of slow-channel CMS is the selective involvement of the cervical and forearm extensor muscles with asymmetric weakness after exercise. ${ }^{3,5}$ Patients with advanced stage disease may have progressive weakness, muscle atrophy, ptosis, and ophthalmoplegia. The progression is thought to be gradual and symmetric. The onset varies from birth to middle age. ${ }^{6}$ On electrodiagnostic testing, a repetitive CMAP, which has also been referred to as a "double hump"7 or "double CMAP," is characteristically seen. A repetitive CMAP can also been seen in other disorders such as CMS due to acetylcholinesterase deficiency, with excessive use of acetylcholinesterase-inhibiting medications such as pyridostigmine, and organophosphate poisoning. ${ }^{8}$

The importance of subtyping CMS is related to the appropriate treatment (table). Pertinent for this patient, the classic symptomatic treatment for autoimmune myasthenia gravis with pyridostigmine is contraindicated in slow-channel CMS. These patients instead symptomatically benefit from openchannel AChR blockers, such as fluoxetine and quinidine. ${ }^{9}$ A 3-year prospective open-label study showed improvement in the clinical examination and on neurophysiologic studies after treatment of fluoxetine $80-120 \mathrm{mg} / \mathrm{d} .{ }^{9}$ Quinidine is also shown effective when serum levels reach a therapeutic range of $1-2.5 \mu \mathrm{g} / \mathrm{mL}$. $^{10}$

By keeping CMS in the differential for fixed and fatigable weakness, patients can receive the correct diagnosis earlier. Most importantly, an accurate diagnosis will prevent patients from receiving unnecessary therapies and instead will be started on appropriate treatment. With the advent and commercialization of genetic testing for neuromuscular disorders, this diagnosis may be more readily made than before. 
Table Selected Congenital Myasthenic Syndrome (CMS) Subtypes, Causative Genes, and Treatments

\begin{tabular}{|c|c|c|}
\hline Subtypes of CMS & Gene & Treatment \\
\hline \multicolumn{3}{|l|}{ Presynaptic } \\
\hline Choline acetyltransferase (ChAT) deficiency & ChAT & Pyridostigmine, 3,4-DAP \\
\hline \multicolumn{3}{|l|}{ Synaptic } \\
\hline Acetylcholinesterase (AChE) deficiency & COLQ & Ephedrine, albuterol; avoid AChE inhibitors \\
\hline \multicolumn{3}{|l|}{ Postsynaptic } \\
\hline Primary acetylcholine receptor (AChR) deficiency & CHRNA, CHRNB, CHRBD, CHRNE & Pyridostigmine, 3,4-DAP \\
\hline \multicolumn{3}{|l|}{ AChR kinetic abnormalities } \\
\hline Slow channel syndrome & CHRNA, CHRNB, CHRND, CHRNE & Quinidine sulfate, fluoxetine; avoid AChE inhibitors \\
\hline Fast channel syndrome & CHRNA, CHRND, CHRNE & Pyridostigmine, 3,4-DAP \\
\hline \multicolumn{3}{|l|}{ AChR complex defects } \\
\hline Rapsyn deficiency & RAPSN & Pyridostigmine, 3,4-DAP, albuterol \\
\hline Dok-7 deficiency & DOK7 & Ephedrine, albuterol; may worsen with AChE inhibitors \\
\hline MuSK deficiency & MUSK & $\begin{array}{l}\text { Albuterol; variable response to pyridostigmine and } \\
\text { 3,4-DAP }\end{array}$ \\
\hline Agrin deficiency & $A G R N$ & Ephedrine, 3,4-DAP \\
\hline Voltage-gated sodium channel & SCN4A & Pyridostigmine, acetazolamide \\
\hline Tubular aggregates/defects in glycosylation & GFPT1, DPAGT1, GMPPB, ALG2, ALG14 & Pyridostigmine, albuterol \\
\hline Plectin deficiency & PLEC1 & Variable response to 3,4-DAP \\
\hline
\end{tabular}

Abbreviations: 3,4-DAP = 3,4-diaminopyridine; Dok-7 = downstream of tyrosine kinase 7; MuSK = muscle-specific tyrosine kinase. Adapted from references 1,3 , and 5 .

\section{Study Funding}

No targeted funding reported.

\section{Disclosure}

The authors report no disclosures relevant to the manuscript. Go to Neurology.org/N for full disclosures.

Appendix Authors

\begin{tabular}{|c|c|c|}
\hline Name & Location & Contribution \\
\hline $\begin{array}{l}\text { Brian } \\
\text { Stephens, } \\
\text { MD, MS }\end{array}$ & $\begin{array}{l}\text { University of } \\
\text { California, San } \\
\text { Francisco }\end{array}$ & $\begin{array}{l}\text { Concept, acquisition of data, and } \\
\text { writing and revising of the } \\
\text { manuscript }\end{array}$ \\
\hline $\begin{array}{l}\text { Min Kang, } \\
\text { MD }\end{array}$ & $\begin{array}{l}\text { University of } \\
\text { California, San } \\
\text { Francisco }\end{array}$ & $\begin{array}{l}\text { Concept, acquisition of data, and } \\
\text { writing and revising of the } \\
\text { manuscript }\end{array}$ \\
\hline
\end{tabular}

\section{References}

1. Farmakidis C, Pasnoor M, Barohn RJ, Dimachkie MM. Congenital myasthenic syndromes: a clinical and treatment approach. Curr Treat Options Neurol 2018;20:36.

2. Engel AG, Lambert EH, Mulder DM, et al. A newly recognized congenital myasthenic syndrome attributed to a prolonged open time of the acetylcholine-induced ion channel. Ann Neurol 1982;11:553-569.

3. Lorenzoni PJ, Scola RH, Kay CS, Werneck LC. Congenital myasthenic syndrome: brief review. Pediatr Neurol 2012;46:141-148.

4. Kao JC, Milone M, Selcen D, Shen X, Engel AG, Liewluck T. Congenital myasthenic syndromes in adult neurology clinic: a long road to diagnosis and therapy. Neurology 2018;91:e1770-e1777.

5. Engel AG. Genetic basis and phenotypic features of congenital myasthenic syndromes. Handbook Clin Neurol 2018;148:565-589.

6. Chaouch A, Muller JS, Guergueltcheva V, et al. A retrospective clinical study of the treatment of slow-channel congenital myasthenic syndrome. J Neurol 2012;259: 474-48.

7. Crawford TO. The floppy infant. In: Neurology in Clinical Practice: Principles of Diagnosis and Management, 4th ed. Philadelphia: Elsevier; 2004; 403-404.

8. Van Dijk JG, Lammers GJ. Repetitive CMAPs: mechanisms of neural and synaptic genesis. Muscle Nerve 1996;19:1127-1133.

9. Harper CM, Fukodome T, Engel AG. Treatment of slow-channel congenital myasthenic syndrome with fluoxetine. Neurology 2003;60:1710-1713.

10. Harper CM, Engel AG. Quinidine sulfate therapy for the slow-channel congenital myasthenic syndrome. Ann Neurol 1998;43:480-484. 


\title{
Neurology
}

\author{
Pearls \& Oy-sters: The Myasthenic Double Humps \\ Brian D. Stephens and Min K. Kang \\ Neurology 2021;96;545-547 Published Online before print December 4, 2020 \\ DOI 10.1212/WNL.0000000000011287
}

This information is current as of December 4, 2020

\section{Updated Information \&} Services

\section{References}

Subspecialty Collections

Permissions \& Licensing

Reprints including high resolution figures, can be found at: http://n.neurology.org/content/96/11/545.full

This article cites 9 articles, 2 of which you can access for free at: http://n.neurology.org/content/96/11/545.full\#ref-list-1

This article, along with others on similar topics, appears in the following collection(s):

All Clinical Neurology

http://n.neurology.org/cgi/collection/all_clinical_neurology All clinical neurophysiology

http://n.neurology.org/cgi/collection/all_clinical_neurophysiology

All Neuromuscular Disease

http://n.neurology.org/cgi/collection/all_neuromuscular_disease

Myasthenia

http://n.neurology.org/cgi/collection/myasthenia

Information about reproducing this article in parts (figures,tables) or in its entirety can be found online at:

http://www.neurology.org/about/about_the_journal\#permissions

Information about ordering reprints can be found online:

http://n.neurology.org/subscribers/advertise

Neurology ${ }^{\circledR}$ is the official journal of the American Academy of Neurology. Published continuously since 1951, it is now a weekly with 48 issues per year. Copyright () 2020 American Academy of Neurology. All rights reserved. Print ISSN: 0028-3878. Online ISSN: 1526-632X.

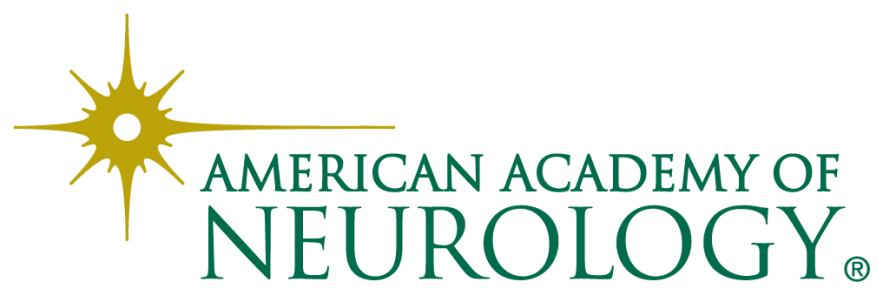

